Middle tibiæ each bearing two or more macrochætæ on the front side near the middle. Hind tibiæ sub-ciliate.

Abdomen black, the segments grayish pollinose on the basal four-fifths, with the exception of the first segment, which is destitute of pollen on the dorsum. A median black dorsal vitta. First and second segments bearing a pair of median marginal macrochætæ, the third a marginal row and the fourth bearing macrochætæ on its apical two-thirds. Hairs of abdomen sub-erect.

Wings hyaline. Apical cell open, ending before the wing tip. The third longitudinal vein bearing two or three bristles at its base. Calypteres whitish, faintly bordered with yellowish.

Puparium $7 \mathrm{~mm}$. in length. The anal stigmata highly raised, sub-cylindrical, nearly $.5 \mathrm{~mm}$. long. Reticulations in three distinct half circular impressions with a small circular impression in the center.

Described from five male specimens.

One male (Holotype) in collection of the U. S. National Museum, Cat. No. 19237 reared from an unknown Noctuid larva taken at Revere, Mass., by Mr. J. V. Shaffner.

Three males (Paratypes) taken by Mr. C. W. Johnson at Sugar Island, Me., July 17, 1907, and Orrs Island, Me., July 21, 1907. In collection of the Boston Society of Natural History.

One male (Paratype) taken by writer at North Andover, Mass., July 16, 1911. In author's collection.

\title{
A NEW WINGLESS PHORID FLY FROM JAMAICA.
}

\author{
By Charles T. Brues, \\ Bussey Institution, Harvard University.
}

Chonocephalus jamaicensis sp. nov.

ㅇ. Length, $1 \mathrm{~mm}$. Brownish yellow; dorsal abdominal plates fuscous; legs brownish-yellow, lighter beyond the femora. Head very slightly wider than long, broadest at the eyes which are quite near the hind angles; the latter rectangular, rounded only at the extreme corner; from just in front of the eyes, the front is narrowed, the edge regularly concave to the fore margin which is strongly arcuate and about two-fifths as broad as the head behind; sides of head below antennal cavities sinuate, convex behind and somewhat concave in front, turning in toward the median line a little before the fore margin of the front; posterior margin of head straight. Surface of head above covered with small, sub-erect hairs, and with a large bristle at the side margin of the front just above the antenna, followed by a series of three smaller ones extending forward along the edge of the front; side of head just below antenna with a group of three rather large and a few small bristles; oral margin fringed on each side with five delicate, downwardly directed bristles; antennæ 
small, rounded, but distinctly angulate at the insertion of the arista which is very long and delicate, reaching to the base of the abdomen. Head, viewed from the side, twice as long as high, flat above and strongly curved downwards in front and backwards to the anterior angle of the antennal cavity; face obtusely produced forward and downward below the oral margin; margin of head below eyes horizontal. Eyes with 15-16 ommatidia. Palpi of moderate size, flattened; with five bristles below and several longer ones at apex. Thorax in dorsal view three times as broad as long on the sides; medially narrowed to half its length at the sides, both the anterior and posterior margins bisinuate; humeri distinctly marked off as rounded tubercles; clothed with sparse fine hairs like those on the head, but without bristles. Abdomen with six fully chitinized plates which fully cover its dorsal surface, except where the sutures extend between them as very narrow membranous bands; first plate nearly semicircular, with straight posterior edge; second to fifth subequal in length, the fourth broadest; along the posterior edge each plate has a black band which bears a series of from 15-20 pale circular dots from each of which arises a bristle about one fourth as long as the width of the plate. Sixth plate a little longer than the preceding, rounded behind, and with four fine bristles on its posterior margin; whole abdomen above, finely, sparsely hairy. Ovipositor more or less exserted, of the usual tubular, soft, fleshy type. Venter with only one plate, that of the sixth segment; this somewhat broader than long, straight in front and on the sides, but concave behind; posterior margin with four small equidistant bristles, one at each angle with a pair between. Legs stout, hairy, but without distinct bristles, except for a tuft of short ones at the tip of the anterior coxæ, a series of five or six on the outer edge of the middle coxæ and one at the tip of the hind coxæ; front tibiæ with one minute spur; middle ones with a larger one and hind ones with a pair of which one is very small.

Williamstown, Jamaica, B. W. I. Type No. 9033 in the Museum of Comparative Zoölogy. Described from specimens given me by Prof. Roland Thaxter.

This species is a close relative of the other forms of Chonocephalus which have already been made known from various parts of the world. This great similarity of the species is most remarkable when it is recalled that the others known from females are from such widely separated regions as the Bismark Archipelago, German East Africa, Sumatra, India, Mexico and Guatemala. On account of their close resemblance I have drawn up a table for their separation. It must be stated, however, that this is in part compiled from descriptions, as I have seen specimens of only three species.

\section{KEY TO THE SPECIES OF CHONOCEPHALUS (FEMALES).}

1. Dorsal abdominal plates of the first to fifth segments with a series of transparent dots along the posterior border from which arise the marginal bristles. . . . 2 
Plates of abdominal segments uniformly pigmented, without transparent dots

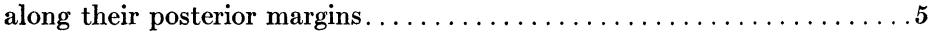

2. Front almost twice as broad behind as long. ...................

Front narrower in proportion to its length; three bristles on lateral margin of front above the antennal cavity.........................

3. Head viewed from the side twice as long as high.. .(Jamaica, B. W. I.)...... jamaicensis Brues.

Head viewed from the side only one-half longer than high. (Bismark Archipelago.).......................... dorsalis Wandolleck.

4. Thorax greatly constricted medially, its length at the sides over twice that at the middle. (Sumatra.)..................... depressus de Meijere.

Thorax less strongly constricted medially, much less than twice as long at the sides as at the middle. (German East Africa.).......kiboshoënsis Brues.

5. Lateral margin of front above antennal cavity with one or more bristles which are much larger than the sparse hairs covering the head ...........6

Lateral margin of front without any bristles above the antennal cavity; fourth dorsal plate of abdomen much longer than the third. (Guatemala.).......

buccata Malloch.

6. Lateral margin of front with a single bristle above the antennal cavity. (Mexico.).............................. mexicanus Silvestri.

Lateral margin of front with three bristles above the antennal cavity. (India.) fletcheri Schmitz.

\title{
AN OBSERVATION ON THE BREEDING HABITS OF STIGMUS CONESTOGORUM ROHWER.
}

\author{
By C. H. Richardson, \\ New Brunswick, New Jersey.
}

In a number of galls of Holcaspis globulus gathered from white oaks on September 13, 1914, at New Brunswick, N. J., was one inhabited by the wasp, Stigmus conestogorum. The dried condition of the gall showed that it had been deserted by the original owners. The wasp had formed numerous passage-ways in the pith which terminated in oval-shaped chambers. These chambers were filled with green aphids upon which larvæ, presumably of this species, were feeding. Since the female wasp was captured in the nest, it is possible that the larvæ of this species are attended by the parent throughout their active feeding period.

Stigmus fraternus and other Pemphredonidæ are said to burrow in the dried pithy branches of various kinds of plants and to fill 

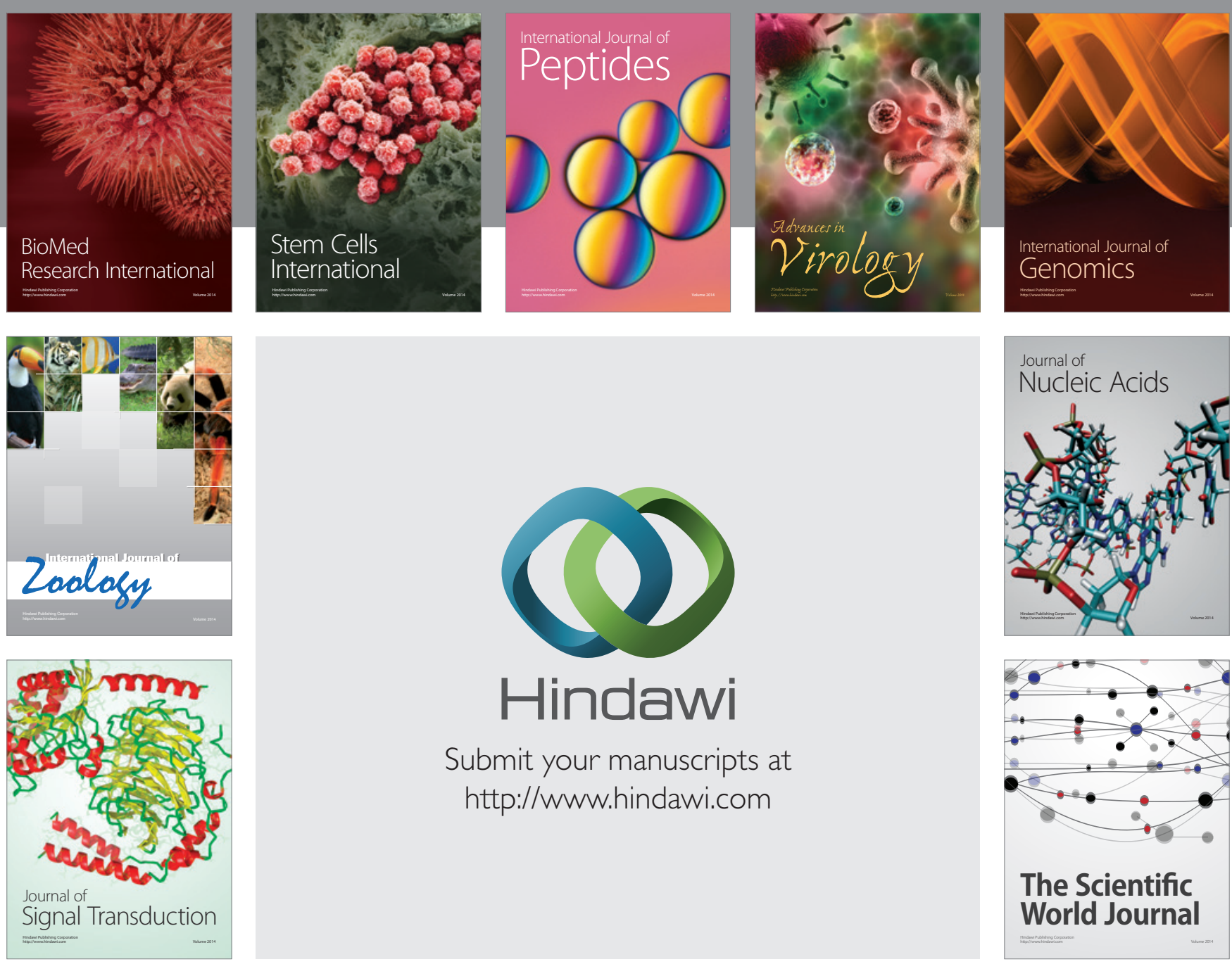

Submit your manuscripts at

http://www.hindawi.com
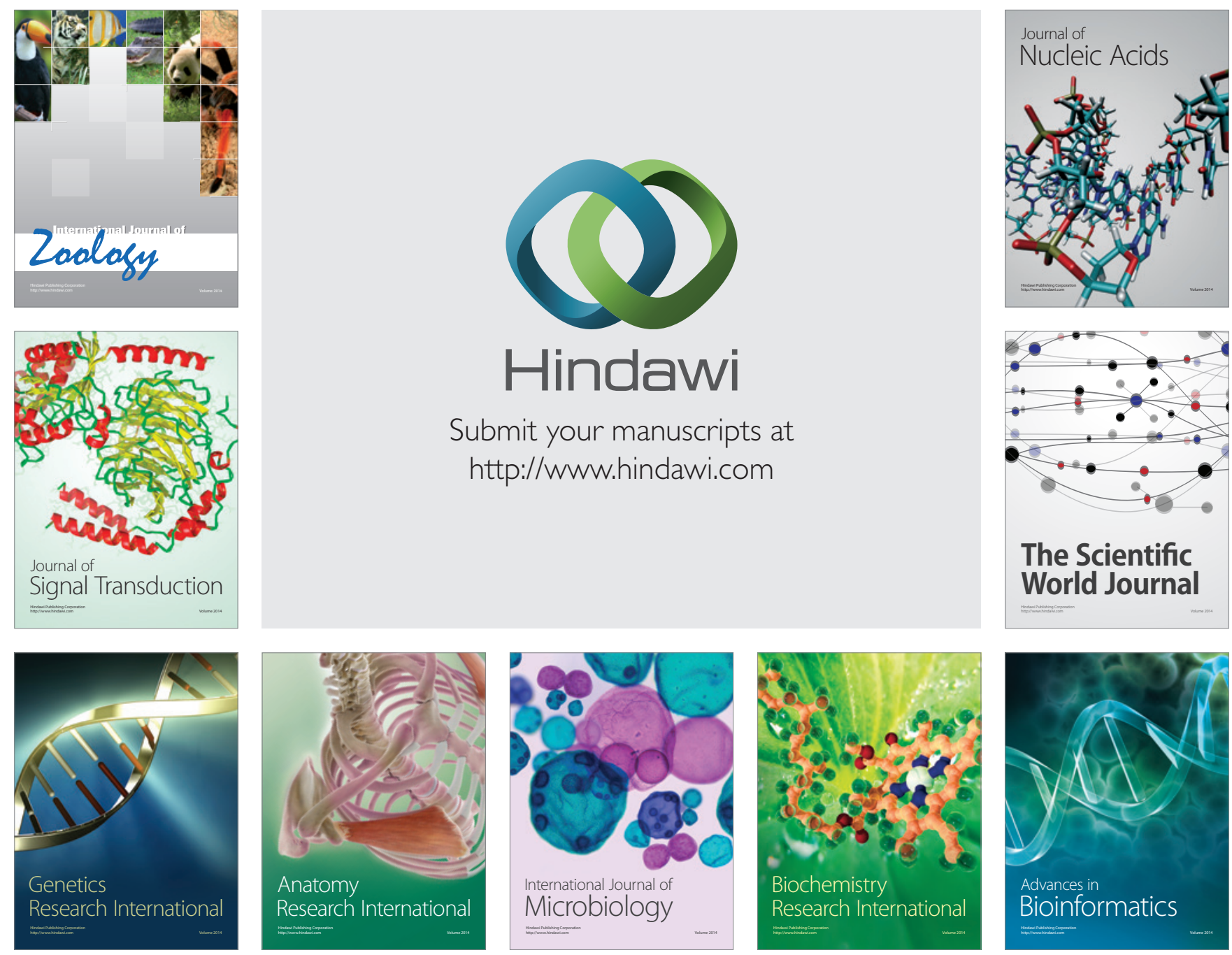

The Scientific World Journal
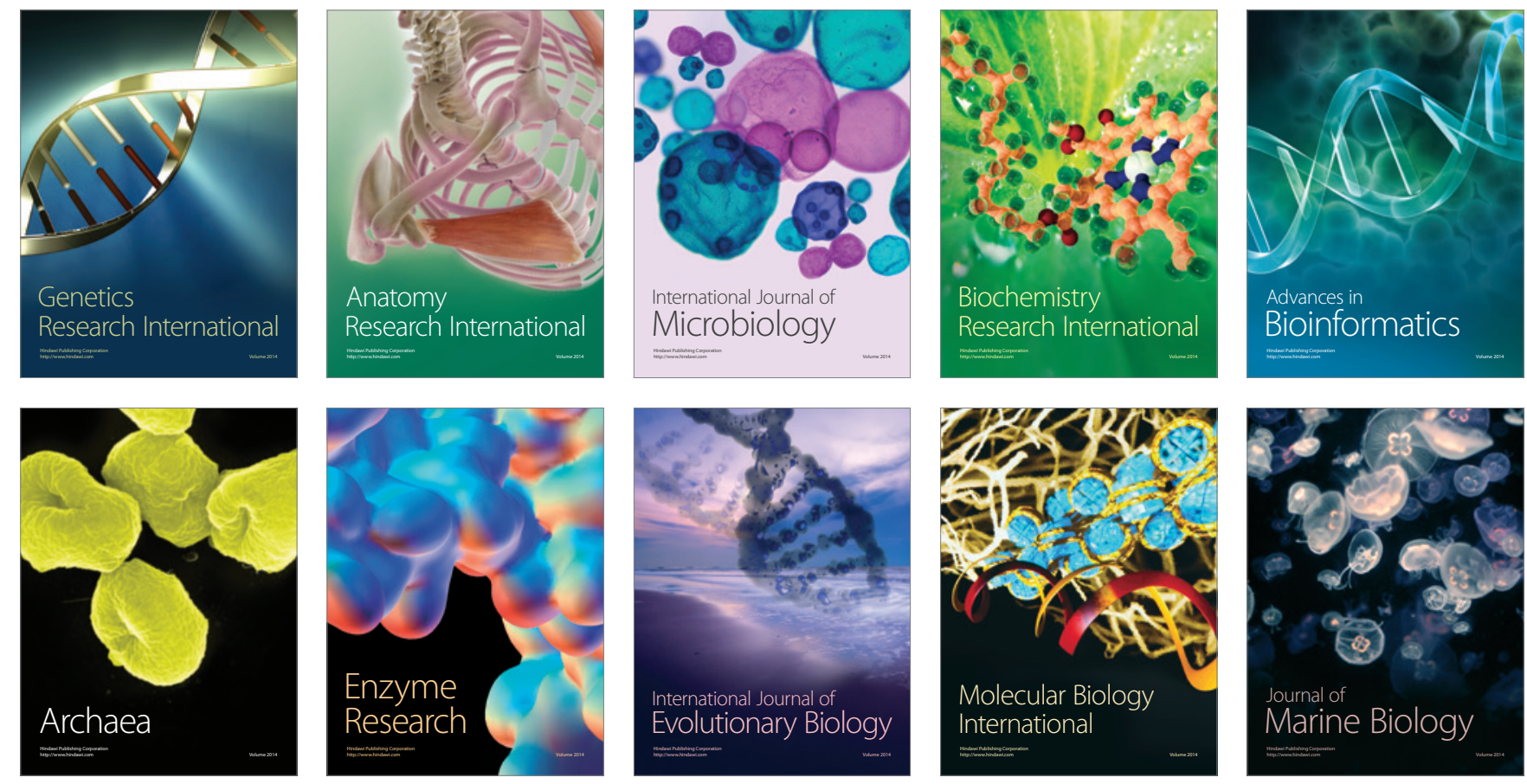